\title{
Lumen
}

Selected Proceedings from the Canadian Society for Eighteenth-Century Studies

\section{'The Force of Language, and the Sweets of Love': Eliza Haywood and the Erotics of Reading in Samuel Richardson's Clarissa}

\section{Kate Williams}

Volume 23, 2004

URI : https://id.erudit.org/iderudit/1012201ar

DOI : https://doi.org/10.7202/1012201ar

Aller au sommaire du numéro

Éditeur(s)

Canadian Society for Eighteenth-Century Studies / Société canadienne d'étude du dix-huitième siècle

ISSN

1209-3696 (imprimé)

1927-8284 (numérique)

Découvrir la revue

Citer cet article

Williams, K. (2004). 'The Force of Language, and the Sweets of Love': Eliza Haywood and the Erotics of Reading in Samuel Richardson's Clarissa. Lumen, 23, 309-323. https://doi.org/10.7202/1012201ar

Copyright (c) Canadian Society for Eighteenth-Century Studies / Sociéte canadienne d'étude du dix-huitième siècle, 2004
Ce document est protégé par la loi sur le droit d'auteur. L'utilisation des services d'Érudit (y compris la reproduction) est assujettie à sa politique d'utilisation que vous pouvez consulter en ligne.

https://apropos.erudit.org/fr/usagers/politique-dutilisation/ 


\section{The Force of Language, and the Sweets of Love': Eliza Haywood and the Erotics of Reading in Samuel Richardson's Clarissa ${ }^{1}$}

Declarations that fiction possessed the power to arouse the reader into a form of sexual pleasure permeated the marketing of the early eighteenth-century novel. My article reviews the circulation of such pronouncements around the work of Eliza Haywood in order to appraise the representation of erotic reading in Samuel Richardson's Clarissa (1747-48). I first consider the descriptions of Eliza Haywood's ability to seduce by writing and evaluate the intimations of her promoters that the sensations furnished by her prose proved superior to real-life desire. After touching on Pamela (1740), I examine how Richardson's use of multiple narrators in Clarissa complicated the conventions of sensual reading. The characters resist the influence of moving language and Lovelace harnesses it to his self-pleasuring fantasy of a submissive Clarissa that arouses no one but himself. In Licensing Entertainment, William Warner presents the relationship between Haywood and Richardson as an unacknowledged 'intertextual exchange'. ${ }^{2}$ The following pages argue that Richardson consciously revised Haywood's tropes to hint at the impossibility of sympathetic interchange between characters and or writer and reader. By dramatising the misunderstandings of a set of individuals who fail to communicate, Clarissa exposes the artifi-

1 I am grateful to Dr Tom Keymer for supervising the thesis from which aspects of my article are drawn and for his valuable comments on my paper. Thanks also to the AHRB and Somerville College, Oxford for enabling me to attend CSECS 2002 in Quebec City.

2 William Warner, Licensing Entertainment: The Elevation of Novel Reading in Britain, 1684-1750 (Berkeley, Los Angeles and London: University of California Press, 1998), p. 193. 
ciality behind the language of affective reading and denies its reader the libidinous response of sighs and tears that Haywood's fiction pledged.

\section{Eliza Haywood and moving the reader}

William Warner asserts that writers such as Eliza Haywood aimed to 'seduce the novel reading body into pleasure' and he aptly dubs such a reading experience 'absorptive'. ${ }^{3}$ Haywood's plots, as Ros Ballaster observes, quested to 'engage the female reader's sympathy and erotic pleasure, rather than stimulate intellectual judgement'. ${ }^{4}$ As Love in Excess (1719-20) was reprinted, it garnered advertisements for its ability to overwhelm the reader with sensual pleasure. James Sterling's 1725 poem eulogised Haywood as the 'Great Arbitress of Passion'. He extols to her how 'the despotick will the limbs, thou mov'st the heart' and how 'Persuasion waits on all your bright designs'. As he claimed,

You sit like Heaven's bright minister on high,

Command the throbbing breast, and wartry eye,

And, as our captive spirits ebb and flow,

Smile at the tempests you have raised below[...].

Her writing is so persuasive that even the most suspicious reader 'reads, forgets herself and smiles'. Sterling concluded his third verse with an orgasmic flourish.

Proportion'd to the image, language swells,

Both leave the mind suspended, which excels -

The subject's merit as a reader is predicated in her readiness to become 'throbbing breast and wartry eye' and then 'melt in soft desires'. Haywood's skill derives from her capacity to enthral the 'captive spirits' of her readers.

Richard Savage's poem, published for the first edition of the second part of Love in Excess rhapsodised how Haywood's 'soul-thrilling accents all our senses wound' and 'strike with softness' and hence when her 'Count pleads, what fair his suit can flye?' Moreover,

Ev'n Nature's self in sympathy appears,

Yields sigh for sigh, and melts in equal tears;

3 Warner, p. 99.

4 Ros Ballaster, Seductive Forms: Women's Amatory Fiction from 1684 to 1740 (Oxford: Clarendon Press, 1992), p. 170. 
For such descriptions thus at once can prove

The force of language, and the sweets of love. ${ }^{5}$

Savage presented Haywood's words as conduits to luxurious sexual experience. The reader expresses her enjoyment by the sighs and tears that are the characters' ejaculatory demonstrations of uncontrollable sexual fervour. When Melliora, fondled by D'Elmont, confesses that she feels for him more passion than 'ever yet bore the name of love' she, gripping his hands, 'bathed 'em in a shower of tears'. ${ }^{6}$ In Haywood, a propensity to lachrymose expression indicates the integrity requisite to personal superiority (hardened manipulators such as Melantha, the Baron and Ciamara never cry). The reader who subordinates him or herself to the 'force of language' and melts into discombobulated and sensual sobs proves his moral excellence and, like Melliora, becomes privy to the 'sweets of love'.

A rash of promotional claims for Haywood's ability to captivate the reader paralleled her literary productivity in the 1720 s (she wrote over thirty works of fiction in the decade). ${ }^{7}$ Jonathan Swift's poem 'Corinna' (1728) and Richard Savage's An Author to be Lett (1729) promote so intently her ability to touch the reader into an erotic trance that we might, to borrow William Warner's apposite term for the responses to Richardson's Pamela, portray them as participating in a 'Haywood Media Event'. ${ }^{8}$ Alexander Pope's editions of The Dunciad in 1728 and 1729 (she also appeared in the versions of $1741-42$ and 1743) recalled the frontispiece of Secret Histories, Novels and Poems (1725) to portray Haywood as a handsome, pearl-draped and 'softly smiling' prize for which two publishers compete by urinating. ${ }^{9}$ Pope indicated the commercial viability of amatory fiction and, by insinuating its power to prompt men to

5 James Sterling, 'To Mrs Eliza Haywood on Her Writings,' p. 1 s. 21-22, 18-20, 31-33, 26, and Richard Savage, 'To Mrs Eliza Haywood on her Novel called Love in Excess,' p. 1 s. 9-16. The poems are reprinted in Eliza Haywood, Love in Excess, ed. David Oakleaf (Peterborough, Ontario: Broadview Press, 2000), p. 277-79, 82-83.

6 Haywood, p. 123.

7 For a full list of Haywood's works see Patrick Spedding, A Bibliography of Eliza Haywood (London: Pickering and Chatto, 2004).

8 Warner, p. 176.

9 Edmund Curll battles for Haywood with William Chetwood in 1728, then Samuel Chapman in 1729 (Chetwood and Chapman did publish her work) and then in 1741-42 and 1743 with John Osborne. See Alexander Pope, The Dunciad in Four Books, ed. Valerie Rumbold (Essex: Longman, 2000), p. 171-177. 
urinate, slyly revised the claim that Haywood's readers vented their passion in ejaculatory tears. ${ }^{10}$ The convention that her prose induced an absorptive response recurred even in insult. In The Authors of the Town (1725), Savage (who by then resented her) did not malign the quality of her work but her inability to touch. He declared that although she 'melts, and swells, and pens luxurious rants' she only succeeds in frustrating herself into a 'sulphurous flame' that is 'strong with lust'. Savage deprived Haywood of the capability to induce tears and moans in order to bestow such an ability on Clio (Martha Fowke) whose 'soft lays' entrance the reader until his or her ' $t$ tears fall, sighs rise, obedient to thy strains' as the 'blood dances in the mazy veins'.11

The amatory practice of claiming power over the reader can be read as a perverse adoption of the strategy censured by Shaftesbury in Advice to an Author (1706). Shaftesbury bemoaned contemporary writers as debased seducers and craven flirts who, just as enchanters steal into the houses of women at night to take them captive, created their readers as sensual slaves. ${ }^{12}$ Such an argument indicates the correlation between susceptible reading and the female subject. Although references in works by men suggested that readers of both sexes enjoyed Haywood's novels, the paratexts and plots pathologise a rapt form of response and explicitly identify it as feminine (Haywood's heroes are not affected by what they read). As Christine Blouch notes, the alacrity of modern scholars to identify an erotic reading response with uneducated female readers hungry for vicarious experience suggests the sexism and 'retroactive class anxiety' of their investigations. ${ }^{13}$ Representations of absorptive reading are advertisements rather than descriptions of actual reading practices.

A susceptibility to the entrancing powers of the image is habitually inflicted onto groups perceived as educationally and politically disenfranchised. As Gillian Beer comments, the 'fear that the romance would

10 Pope's poem recalls how Jonathan Swift's Gulliver's Travels (1726) links urination and romance reading when the hero extinguishes a fire caused after a maid fell asleep whilst reading.

11 Savage, The Authors of the Town (1725) reprinted in Haywood, Love in Excess, p. 272.

12 Antony Ashley Cooper, Third Earl of Shaftesbury, Characteristicks of Men, Manners, Opinions, Times, ed. Philip Ayres (Oxford: Clarendon Press, 1999), 1: p. 107-108, 178.

13 Christine Blouch, “What Ann Lang Read": Eliza Haywood and her Readers,' in The Passionate Fictions of Eliza Haywood: Essays on her Life and Work, eds. Rebecca P. Bocchicchio and Kirsten T. Saxon (Kentucky: University Press of Kentucky, 2000), p. 305. 
seduce the imagination' may have expressed a 'recognition that women's lives were very circumscribed in their actual possibilities' ${ }^{14}$ To present a woman obtaining a thrill from a novel was to reveal her as deprived of other sources of stimulation. Such confidence in art's capacity to influence its consumer, particularly those defined as excluded, betrays our adherence to the Lockean concept of response as learned that underpinned the notion of affective reading. ${ }^{15}$ In amatory fiction, women's desire is fostered by reading love stories and likewise Savage's prefatory poem to Love in Excess suggests that if the actual reader submits to the 'force of language' of the novel, he or she too shall experience sexual passion or the 'sweets of love'.

\section{Haywood's Novels}

The eponymous protagonist of Lasselia: or, the Self-Abandon'd (1723) is 'insensible' to love until she encounters her married neighbour Monsieur de l'Amye (his nose bleeds onto her handkerchief). Lasselia reads his poetry and soon her 'Fancy took the part of Passion'. Losing herself in a 'Train of Images', she envisions him 'melting in amorous Languishments'. She loves to 'kiss, embrace, and possess, in Idea, a thousand nameless Joys, which Love too soon inspires a Notion of' and is soon 'ravish'd in Contemplation'. Texts such as Lasselia would invite a reading in which the stage of imaginary passion must be sloughed off for the real (and phallocentric) desire, if Haywood had not dramatised the former as more appealing than the latter. Lasselia's fantasies of queenly dominance over a melting man are shattered by her actual sexual experience. L'Amye assails her with physical force and argument until she is 'at last resistless' and 'trembling 'twixt desire and fear'. He perceives sex as a revelation of his triumph through the 'Gratification of his Wishes'. ${ }^{16}$

In Love in Excess, D'Elmont finds Melliora, who previously disdained softening love stories, in a reverie over Ovid's Epistles. He is gratified by her newfound sensibility to erotic impression but he insists she compre-

14 Gillian Beer, The Romance (London: Metheun, 1970), p. 53.

15 For an argument that critics and writers invest in the convention that writing affects to justify their own literary endeavours, see Leah Price, Anthology and the Rise of the Novel: From Richardson to George Eliot (Cambridge: Cambridge University Press, 2000), p. 20.

16 Eliza Haywood, Lasselia: or, the Self-Abandon'd, ed. Jerry C. Beasley (Kentucky: University Press of Kentucky, 1999), p. 108, 117, 115, 117, 116. 
hends the inferior nature of her feeling to what would be produced by actual sexual intercourse. He informs her that 'once the fancy is fixed on a real object, there will be no need of auxiliary forces, the dear idea will spread it self thro' every faculty of the soul, and in a moment informs us better, than all the writings of the most experienced, could do in an age'. ${ }^{17}$ Yet sexual love in Haywood's fiction, because it is harnessed to the man's pride, never pleasures the woman. As conception was generally considered to occur only if the woman climaxed, it is unsurprising that heroines seldom fall pregnant. ${ }^{18}$ Furthermore, sex does not inspire men to love and they desert soon after they conquer. Haywood's practice of identifying women's integrity with a propensity to erotic feeling yields infelicitous denouements. The true heroine weeps and sighs with a sexual desire so overwhelming that it supersedes her loyalty to her family and friends but her proclivities render her vulnerable to seduction and unless, as in Love in Excess, her admirer's attempts are prevented by interruption, she is ruined and dies.

Haywood's fictions insinuate that the only delight available to women is the solitary erotic daydream of throbbing and weeping in response to a fictional representation of the 'sweets of love'. Such a suggestion might comfort readers who considered themselves injured and excluded. Certainly, privileging private erotic reverie, which could be described in mainstream fiction, over heterosexual intercourse, which only literature termed obscene might fully depict, offered the reader illicit pleasure under the guise of decency. A heroine who is prone to desire may condemn herself but the revelation of her emotional state allows the reader to indulge in her feelings. Moreover, the prefaces define the reader's delight in the scenes of sexual congress as sympathy. Haywood's paratexts render acceptable the type of representation typically found in pornographic literature by instructing readers to perceive their enjoyment of scenes of near-rape as the revelation of their moral worth.

17 Haywood, p. 108.

18 For beliefs about conception, see Angus McLaren, Reproductive Rituals: The Perception of Fertility in England from the Sixteenth Century to the Nineteenth (London and New York: Methuen, 1984), p. 18. 


\section{Richardson}

Richardson claimed to revile the novels that apparently provoked readers into a self-indulgent rhapsody of desire, but in the same year as he composed Pamela he wrote a preface advertising the stirring power of such writing. The 1739 Preface to the Collection of Penelope Aubin's novels, which is largely accepted as authored by Richardson, trumpeted the dramatic effect of perusing a few hundred printed pages. ${ }^{19}$ He wrote that novels may 'inculcate into their [readers'] Minds' to create either 'happy or pernicious Effects on their Future Lives and Morals'. ${ }^{20}$ The Apprentice's Vade Mecum (1734) dwelt fretfully on the invidious influence of the 'glittering, the dazling Scene' and its actresses on apprentices. ${ }^{21} \mathrm{~A}$ Seasonable Examination of the Pleas and Pretensions of the Proprietors of, and Subscribers to, Play Houses (1735) intimated that the seductive and anti-social illusions conjured by drama could 'intoxicate' viewers into reproducing the promiscuous and criminal behaviour of the 'Vilest Miscreants'. ${ }^{22}$ In the preface to Aubin, Richardson converted the verbs of distraction, allurement and disintegration that he had previously associated with the experience of watching a play to express the sexual effect of reading lascivious fiction. Novelists, as sinful as fallen angels, wished to seduce others into being as 'lost and ruined as themselves'. The reader becomes the desiring signifier of physical response, her 'weaker and more glittering Fancies' caught by the erotic web of the sensual scenes. ${ }^{23}$

Keith Maslen has made the pioneering discovery that Richardson printed two of the volumes of Haywood's Secret Histories Novels and Poems for its third printing in 1732, which included Love in Excess. ${ }^{24}$ Richardson's decision to preface the second edition of Pamela in 1741

19 See Wolfgang Zach, 'Mrs. Aubin and Richardson's Earliest Literary Manifesto (1739),' English Studies 62 (1981): p. 271-85. See also Thomas Keymer, 'Introduction,' to Pamela; or, Virtue Rewarded (Oxford: Oxford University Press, 2001), p. xxi, n. 31.

20 Samuel Richardson (attrib.), Preface to Penelope Aubin, A Collection of Entertaining Novels and Histories (London, 1739), p. iii.

21 Samuel Richardson, The Apprentice's Vade Mecum, ed. Alan Dugald McKillop (William Andrews Clark Memorial Library, University of California: Augustan Reprint Society, 1975), nos. 169-70, p. 11.

22 Samuel Richardson, A Seasonable Examination of the Pleas and Pretensions of the Proprietors of, and Subscribers to, Play-Houses [...] (London, 1735), p. 19, 20.

23 Richardson (attrib.), Preface to Aubin, Collection of Entertaining Novels, p. iii.

24 See Keith Maslen, Samuel Richardson of London, Printer (Dunedin, New Zealand: Otago University Press, 2001), p. 90. 
with a letter in which Aaron Hill teasingly described his absorptive response to the novel seems, in consequence, significant for Hill was strongly associated with Haywood. The pair had been close friends in the 1720s and she had explicitly advertised their amity in An Injur'd Husband (1722), Memoirs of a Certain Island (1724) and the poetry published in the second volume of Secret Histories. ${ }^{25}$ His letter evoked Haywood's fiction as a context for Pamela

All the Passions are His, in their most close and abstracted Recesses: and by selecting the most delicate, and yet at the same time, most powerful, of their Springs, thereby to act, wind and manage the Heart, He moves us every where [...]. ${ }^{26}$

Hill's choice of phrase recalls Sterling's representation of Love in Excess as controlling the passions to such a painful extent that its reader wishes her 'delicate texture' less refined for 'weak's the clock with over-curious springs'. ${ }^{27}$ When he confessed he was 'inextricably in Love with this delightful Defect [...] Excess', a proximity of terms that he emphasises with italics, Hill furnished a studied clue to the name of the novel, printed by Richardson, that informed his interpretation of Pamela as supplying 'livelier Rapture, than the Loose can dream' ${ }^{28} \mathrm{He}$ extolled how the tale takes 'Possession, all Night, of the Fancy' and recalled Shaftesbury's lurid comparison of pleasing fiction to an enchanter seizing captives at night. The actual novel dramatised writing as similarly affecting. Mr B.'s moral transformation occurs after he proves susceptible to Pamela's papers. His description of her scripts as a 'very moving Tale' that, he tells her, 'has touched me sensibly' reveals his vulnerability to sympathy and hence his potential moral excellence..$^{29}$ The climax that provokes their marriage soon ensues.

The anti-Pamelist texts were preoccupied with Pamela's power to touch B through styling herself. Haywood's return to the literary marketplace, Anti-Pamela, or Feign'd Innocence Detected (1741), featured the

25 On the friendship between Hill and Haywood, see Christine Gerrard, Aaron Hill: The Muses' Projector 1685-1750 (Oxford: Clarendon Press, 2003), p. 67-70.

26 Aaron Hill, 'To the Editor of Pamela', reprinted in Samuel Richardson, Pamela; or, Virtue Rewarded, eds. Thomas Keymer and Alice Wakely (Oxford: Oxford University Press, 2001), p. 506.

27 Sterling, 'To Mrs Eliza Haywood', p. 1 s. 11-13, reprinted in Haywood, Love in Excess, ed. Oakleaf, p. 277.

28 Hill, 'To the Editor', in Richardson, Pamela, eds. Keymer and Wakely, p. 507, 518, 506.

29 Richardson, Pamela, p. 240-41. 
heroine most accomplished at self-presentation. Syrena prepares to be a seductress by practising to create bodily 'Agitations', her 'Colour would come and go, her Eyes sparkle, grow Languid, or overflow with Tears' just as a heroine in Secret Histories blushed, sparkled, sank into languor and wept. She makes her bosom heave as her limbs tremble, she faints and appears 'transported' in an entirely 'natural' manner. She is as skilled as the 'most experienc'd Actresses' at 'assuming all the different Passions that find Entrance in a Female Mind'. ${ }^{30}$ In Anti-Pamela, Haywood recuperated the language of female erotic sensitivity and true feeling from her 1720s novels to suggest how such reactions might be feigned.

In Clarissa, Richardson developed similar suggestions of the fabricated nature of the female erotic response as his approach to absorptive reading became more convoluted. The structure of multiple correspondents allowed him to transpose the anti-Pamelists' suspicion of feminine self-presentation into the attitude assumed by the Harlowes and Lovelace towards the heroine's writing. They slur Clarissa's writing as falsely persuasive and approach her letters armed with hostile interpretations. ${ }^{31}$ Clarissa proves equally obdurate to influence as she disregards Anna's warnings against Lovelace and is sceptical of her friend's sympathy with Rosebud (p. 285-86). The Harlowes, Lovelace and Clarissa trust in their power to move and persuade (even Antony Harlowe writes that he has 'the argument on my side' (p. 158)) but they are impervious to the power of any other character's language. Erotic sympathy is not prompted, as in Haywood through words, but by Clarissa's efforts to manipulate herself into a pictorial image. ${ }^{32}$ Action and alteration are produced by physical force.

Lovelace and the Harlowes acquaint subordination to moving language with weakness. Clarissa's family refuse to read her letters and prevent her from writing, because, as Arabella declares, 'your whining

30 Anti-Pamela and The Memoirs of Lady H, vol. 3 of The Pamela Controversy: Criticisms and Adaptations of Samuel Richardson's Pamela 1740-1750, eds. Thomas Keymer and Peter Sabor (London: Pickering and Chatto, 2001), p. 6-7. A new paperback edition of Anti-Pamela, edited by Catherine Ingrassia, is published by Broadview in 2004.

31 All references are to the modern reprint of the first edition of the novel, Clarissa; or the History of a Young Lady, ed. Angus Ross (Harmondsworth: Penguin, 1987) and are indicated in parentheses in the text.

32 Margaret Doody notes the significance of the visual image to Clarissa, Margaret Doody, A Natural Passion: A Study of the Novels of Samuel Richardson (Oxford: Clarendon Press, 1974), p. 217-40. 
flourishes make us all dance after your lead' (p. 140). Mrs Norton writes after Clarissa has fallen ill to solicit Mrs Harlowe to read her letters, but the latter replies, 'we are no less acquainted with the unhappy body's power of painting her distresses so as to pierce a stone' (p. 1156). Her brother instructs the family to mistrust the letter that Clarissa sends from her deathbed because of her 'talent [...] of moving the passions' (p. 1323). And yet although Clarissa is cast as a writer who seduces the unwary reader, her letters fail to charm or convince. The Harlowes refuse to believe she was raped and even Colonel Morden considers her seduced by promises of marriage (p. 1280). Her coffin prompts her family's penitence but they later discount the legacies and requests in her will. Lovelace ignores every word that Clarissa writes unless he can distort it to correlate with his self-presentation as sexual conqueror and he mocks her as an actress (like Syrena Tricksy) performing false 'female deaths and revivals' (p. 1084).

When Belford queries that, if the relater is 'unmoved by his own story, how then able to move the hearer or reader?', he evokes the amatory paradigm of sympathy as produced by participating in the verbal description of the heroine's emotional state. And yet he is not touched by Clarissa's writing or the rapturous speeches with which she embraces death but by her appearance and her pose in the arms of Mrs Lovick (p. 1065,1351 ). He is possessed (recalling how Hill claimed to be entranced by the witchcraft of Pamela) by nightmares about the symbols on Clarissa's coffin and his focus on her body is divulged by his bizarre description of her as a 'lovely skeleton' (p. 1305, 1231). Only when Clarissa adopts the strategy of styling herself to signify her ambition (a practice that Henry Fielding exploited in Shamela (1741) for comic purpose), does she win sympathy and thus a modicum of self-direction. The sole occasion when Lovelace is impressed by her language is when, after the rape, Clarissa refuses to execute the 'high passions, raving' and 'transient violences' he had anticipated. Her 'majestic composure' provokes his 'confusion' and 'broken sentences' (p. 900). Like Belford, Lovelace is not affected by her language but by its absence.

William Warner presents Richardson as reforming and expelling the absorptive promises of amatory writers yet a consideration of representations of reading in Clarissa indicates a more complex relationship with amatory fiction than mere expurgation. ${ }^{33}$ As Margaret Doody demonstrates, Haywood's representations of a woman's experience of sexual 
desire formed a crucial source for Richardson's dramatisation of a 'natural passion' ${ }^{34}$ This essay is indebted to Doody's approach but I argue that Richardson shows the characters conspicuously reworking amatory lexicons to reveal the derivative quality of desire. The characters in Clarissa are amatory readers who purloin Haywood's conventions for their own purposes. Lovelace, in particular, deliberately converts a discourse of consensual sex to pursue a rakish code in which a woman discovers sexual passion through rape. His letters harness the terms for female passion claimed by Haywood as absorptive in order to present Clarissa as his grateful concubine.

In Love in Excess, Melliora and D'Elmont embrace and she, 'sunk wholly into his arms', begs him to feel sympathy for her 'most susceptible and tender heart'. She tells him that 'you may feel it throb, it beats against my breast, like an imprisoned bird'. Soon 'both their souls seemed to take wing together' ${ }^{35}$ Lovelace describes Clarissa at the garden gate by mimicking Haywood's representation of feminine ecstasy as surprise, then a dip to languor, followed by desire. Then, after the 'fire' of Clarissa's 'starry eyes began to sink into a less dazzling languor':

She trembled: nor knew she how to support the agitations of a heart she had never found so ungovernable. She was even fainting, when I clasped her in my supporting arms. What a precious moment that! How near, how sweetly near the throbbing partners! (p. 400)

Clarissa's swoon is prompted by her surprise and fear but Lovelace portrays her by using the vocabulary employed by Haywood to illustrate Melliora's passion for her guardian (he also replicates the exact succession of responses rehearsed by Syrena Tricksy). Lovelace depicts 'throbbing' Clarissa as the amatory reader of himself. In her novels, Haywood communicates sexual emotion by presenting the woman as either torn by the 'Love and Honour [that] rack the divided Soul' or overwhelmed with confusion as 'there is no greater proof of a vast and elegant passion, than being uncapable of expressing it' ${ }^{36}$ Lovelace per-

34 Doody, p. 18-19 and see also p. 139-49; See also Catherine Ingrassia, Authorship, Commerce and Gender in Eighteenth-Century England: A Culture of Paper Credit (Cambridge: Cambridge University Press, 1998), p. 149-50.

35 Haywood, p. 90, 124.

36 Eliza Haywood, The Fatal Secret, in Secret Histories, Novels and Poems (London, 1725), p. iii, 219; Haywood, p. 101. 
sistently twists such tropes of division or confusion to discount Clarissa's resentment. When she is angry, he extols how she is split by desire for him as 'unequal partners pull two ways, and the divinity within her tears her silken frame' or relishes her 'charming display of innocent confusion' (p. 647, 491-92). He yokes the language that Haywood identified as conferring the female reader with autonomous ecstasy to his endeavour to diminish Clarissa into the expression of his desires.

In the scene where he invades Clarissa's chamber under the pretence of a fire, Lovelace portrays her reactions by collapsing together two lexicons that are in Haywood distinct. He melds the anatomising language employed to evoke the aggressive gaze of the rake with the vocabulary of throbbing, trembling, weeping and glowing with which Haywood's narrators and heroines (but not heroes) communicate female desire and touch the reader into a similar reverie of passion. In Love in Excess, D'Elmont stares at a sleeping Melliora in a 'most charming dissabillee'. He savours how her 'hair unbraided, hung down upon her shoulders with a negligence more beautiful than all the aids of art could form' as 'part of it fell on her neck and breast, and with it's lovely shadyness' set off 'the "matchless whiteness of her skin'. Her 'loosely flowing' nightgown 'discover'd a thousand beauties which modish formalities conceal' ${ }^{37} \mathrm{D}^{\prime}$ Elmont's endeavour to create Melliora's unconscious body as the signifier of his intrusive desire recurs in Lovelace's description of Clarissa as an 'assemblage of beauties' that 'offered itself at once to my ravished sight' (the phrase 'offered itself' indicates how he reads her postures as consent). He combines the itemising discourse of the rake with the language that Haywood uses to describe female passion to represent Clarissa to his own advantage.

her streaming eyes lifted up to my face with supplicating softness, hands folded, dishevelled hair; for her night head-dress having fallen off in her struggling, her charming tresses fell down in natural shining ringlets, as if officious to conceal the dazzling beauties of her neck and shoulders; her lovely bosom too heaving with sighs, and broken sobs, as if to aid her quivering lips in pleading [...] (p. 725).

Lovelace twists Clarissa's pleadings in order to fashion her as the absorptive reader of his person and his cunning. She is 'streaming', 'supplicating' 'soft', 'dishevelled', 'struggling' 'shining', and she expresses herself by sighing, sobbing and quivering, like Sterling's reader 
of Love in Excess. Haywood developed an ecstatic language organised around terms such as 'dazzling', 'throb', 'ungovernable' and showed women fainting, weeping and trembling in order to represent a feminine sexual desire independent of male attempts. Such representations also touch the reader into a pleasurable reverie. Lovelace harnesses what was in Haywood a lexicon of autonomous feminine desire to his campaign to present Clarissa as welcoming his attempts. ${ }^{38} \mathrm{He}$ attempts to deny her the possibility of a language of female resistance or indeed feeling outside of his objectifying perspective.

Lovelace purloins the language of absorptive reading but his ingenious revisions of Haywood's fiction fall flat. Belford fails to endorse his approach and instead so sympathises with Clarissa that Lovelace mocks his response to her as being 'Belforded all over' (p. 1217). Richardson's hero entrances only himself for, unlike Haywood's D'Elmont, he lacks persuasive powers. Clarissa is not tempted to flee by his letters or speeches but by Joseph Lehman's imitation of armed men. He cannot induce her into desire through books or promises and resorts to drugging and raping her with the paid assistance of prostitutes and Sinclair. Similarly, Belford's diligent representation of Clarissa's virtuous attitude cannot dissuade Lovelace, preoccupied with his own feelings, from believing she secretly loves him, is pregnant by him (by which he implies that she found the rape pleasurable), and wishes to be his wife. The Harlowes and Lovelace refuse to abjure their positions of cool critique and what they consider intellectual judgement for empathy. Clarissa exposes the private and self-pleasuring rhapsodies that underpinned Haywood's novels as productive only of isolation.

Amatory fiction presented language as able to produce a spontaneous change in the reader and instigate a physical response superior to bodily desire. Clarissa dramatises how the language of absorptive reading fails to affect or persuade. In Richardson's novel, epistolary interaction is anything but a communication that produces sympathy and it is impossible to feel overwhelming erotic sensation because one is everywhere aware of the fabricated and derivative quality of such a reaction. As Richardson reveals sentiment as reliant on representation and feelings as created by exposure to corrupted fiction, he uncovers the relationships between characters, and indeed between reader and writer as founded

38 As Tassie Gwilliam comments, Lovelace constructs 'images and interpretations of Clarissa, and particularly of Clarissa's body' that makes her 'available psychically and physically to him' (Tassie Gwillam, Samuel Richardson's Fictions of Gender (Stanford: Stanford University Press, 1993), p. 81, 83). 
on self-consciousness and misrepresentation. The only love felt by the main characters in Clarissa is the type of love that the text disparages: self-indulgent and dependent on fictional models rather than a response to a person. In consequence, its readers are left frustrated rather than aroused. Clarissa evokes the trappings of an absorptive novel by proffering a throbbing heroine and a rapacious hero but, by emphasising the imitative nature of the feelings that the pair expounds, Richardson deprives his reader of the possibility of an erotically thrilling encounter with his text.

Richardson's denial of the ability of the author to captivate others through words was not conclusive. Although he interrogated the ability of authors to seduce others through words, he encouraged his female readers to confess their passionate responses to the novel. The letters from women such as Lady Bradshaigh, Mary Delany, Susanna Highmore and Sarah Chapone assigned a framework appropriate to amatory reading onto Clarissa. Susanna Highmore describes how Anna's 'Grief' is 'described in so lively a Manner' that it was 'more than I could bear, I laid down the book' as she 'felt' as 'much Affliction as a Friend in real life'. She continued that she feels as if the 'like affecting Scenes' are before her as 'I see, hear, I feel the same, and am for the present as unhappy, as if it were all true'. Highmore revised into a confession of virtuous sympathy the scene in Love in Excess where Melliora laid down Ovid to dream (and the reverie of Aaron Hill over Pamela). She details how she 'dream' $d$ ' of Clarissa's family as 'my own Imagination represented it' and concludes that that nobody can read them without streaming Eyes, and heart-breaking Sorrow' ${ }^{39}$ Lady Bradshaigh felt similarly.

Had you seen me I surely should have moved your Pity. When alone in Agonies would I lay down the Book, take it up again, walk about the Room, let fall a Flood of Tears, wipe my Eyes, read again, perhaps not three Lines, throw away the Book crying out Excuse me good Mr Richardson I cannot go on. It is your Fault you have done more than I can bear, threw myself upon my Couch to compose. ${ }^{40}$

Bradshaigh regrets her failing but Richardson encourages her to continue by suggesting that she calls her 'Susceptibility' not weakness but 'Humanity, and see how your Sentences will run'. ${ }^{41}$

39 Susanna Highmore to Richardson, January 2 1749, Forster Collection XV, f. 24.

40 Lady Bradshaigh to Richardson, January 6 1749, FC XI, ff. 12-14.

41 Richardson to Bradshaigh, n.d. (1749?), FC XI, f. 7. 
After Richardson, sentimental novelists borrowed tropes from Clarissa but veiled its revelation of the derivative quality of emotion to lay faith in tears and sighs indicative of true feeling and to enshrine the moral excellence of characters who responded to representations of pain and distress. The correlation between writer and seducer, textual enjoyment and sexual enjoyment persisted. Anna Laetitia Barbauld concluded her preface to Clarissa, in her Collection of the British Novelists (1810) with Thomas Edward's poem, "To the Author of "Clarissa"'. In the poem, Richardson, reflecting Sterling's representation of Haywood, is the 'Master of the heart! whose magic skill [...] Now melt with pity, now with anguish thrill' ${ }^{42}$ Despite what Clarissa suggests about the writer's power to affect, the amatory notion of reading as the experience of erotic subordination to the text was too intoxicating for most writers and readers to resist.

KATE WILLIAMS

University of Oxford

42 'Sonnet to the Author of Clarissa' in Clarissa, vol. 1 of The British Novelists; with an Essay and Prefaces Biographical and Critical, ed. Anna Barbauld (London, 1810), p. iii. 